\title{
O sentimento trágico do século XIX*
}

\author{
Araripe Júnior ${ }^{* *}$
}

Resumo: Texto publicado no anuário carioca Almanaque Garnier, em 1904. Nele Araripe Júnior procura abordar o sentimento trágico do século XIX; para tanto, parte do primeiro livro do jovem Nietzsche, A origem da tragédia. $\mathrm{O}$ autor sustenta que o sentimento trágico encontrado na obra do jovem Nietzsche não corresponde ao sentimento trágico grego, mas ao sentimento trágico moderno, em particular do século XIX.

Palavras-Chave: Nietzsche - sentimento trágico $-A$ origem da tragédia

$\mathrm{Na}$ sua interessante obra, A origem da tragédia, Nietzsche propõe-se definir o sentimento trágico tal qual deveria ter existido entre os gregos.

Parece, porém, que o filólogo se deixou trair pelo sentimento da modernidade. Nietzsche, em lugar da tragédia grega, esboçou o paganismo do século XIX. Esse neopaganismo acabou por concretizar, em seu espírito, as tendências, algo paradoxais, da filosofia da grandeza pelo instinto.

Seja, entretanto, como for, o gênio desse escritor, para não dizer desse poeta, ultrapassou, em penetração os mais cheios de

* Publicado no Almanaque do Garnier (A.B.G.). Rio de Janeiro, ano de 1904, p. 01. Depois reeditado na Obra Crítica de Araripe Júnior, Volume V. 1911, p. 86-89.

** Tristão de Alencar Araripe Júnior (1848-1911). Crítico, cronista e membro da Academia Brasileira de Letras. 
emotividade trágica do século passado. E foi semelhante emotividade estranha que o seu espírito crítico transferiu para essa arte helênica, que os críticos, quase universalmente convinham em achar tão singularmente tranquila, modulada e grave, na serenidade dos olhos sem pupilas das suas estátuas de puro mármore.

Sempre cuidei que por baixo da placidez dos mármores helênicos, havia alguma coisa de tumultuoso e até macabro, que, à nossa vista míopes, era vedado descobrir, do mesmo modo que é impossível discernir a paixão que trucidou a formosa egípcia, hoje mumificada na intraduzibilidade do sarcófago, onde depositou o carinho do Faraó de há cinco mil anos. Mas, daí para o que a Nietzsche se afigura, vai um grande esforço; - contraste que me leva a crer na metáfora operada em seu espírito pelo excesso de atenção prestada aos monumentos legados por aquela grande cultura artística.

O pensador alemão prevê a ressurreição da tragédia dionisíaca. Não é sem arrepio de espanto que se lê esta imprecação:

Crede amigo, meus amigos, na vida dionisíaca e na renascença da tragédia. Os tempos do homem socrático passaram. De tirso em punho, coroai-vos de pâmpanos; e não vos mostreis espantados se o tigre e a pantera vierem deitar-se, festivos, mansamente aos vossos pés. Tende coragem, e agora é assumir a atitude dos homens trágicos: e porque sois livres, não vos escuseis ao trabalho glorioso de escoltar o cortejo dionisíaco da Índia e da Grécia! ${ }^{1}$

A convicção de Nietzsche é grande e comunicativa. Que é a vida na sua opinião? É um mistério resolúvel na tragédia. A despeito do terror e da piedade, é preciso que gozemos a felicidade de viver "não tanto enquanto indivíduos com vida nua, total, confundidos e absorvidos na alegria criadora".

1 Nietzsche, L'Origine de la Tragédie, p. 187. Trad. Marnold. Paris, 1901.

108 | Cad. Nietzsche, São Paulo, v.36 n.1, p. 107-111, 2015. 
A história das origens da tragédia grega, - acrescenta o crítico, - nos revela, com precisão luminosa, o modo porque a obra d'arte trágica dos gregos nasceu realmente do gênio da música; e com o auxilio dessa ideia, acreditamos ter, pela primeira vez, exatamente interpretado o sentimento primitivo e singular do coro. Mas é preciso convir em que o alcance do mito trágico, tal qual o estabelecemos, nuca foi percebido, com nitidez manifesta, pelos poetas e ainda menos pelos filósofos da Grécia; a linguagem de seus heróis é, até certo ponto, mais superficial do que seus atos; o mito não encontra, por forma alguma, objetivação adequada no discurso. A sucessão das cenas e o espetáculo dos quadros proclamam uma sabedoria mais profunda do que o próprio poeta é capaz de atingir por meio de palavras e das ideias. Fenômeno semelhante pode observar-se em Shakespeare, cujo Hamlet, por exemplo, numa acepção análoga, fala mais superficialmente do que obra, de sorte que não é das palavras, mas da profunda contemplação do conjunto que se deduz essa filosofia de Hamlet, precedentemente exposta. ${ }^{2}$

E assim chega-se até ao pensamento original de que em futuro próximo, abandonada a "moral de atitudes", de Sócrates, a "hipocrisia dos humildes", do cristianismo, e a "virtude utilitária" da democracia moderna, o homem como o grego dionisíaco, e agora com mais força, graças ao que a experiência lhe tem ensinado, saberá querer a verdade e natureza em todo o seu esplendor e, de modo novo, se metamorfoseará em sátiro.

Os heróis tiveram, na Idade de Bronze, os seus combates de Titãs. As monstruosidades dessa época lhes geraram o amargor da vida, donde, pouco a pouco, saiu o mundo homérico, sob a influência tutelar do instinto da beleza apolínia. Esse esplendor ingênuo foi devorado pela invasão ruidosa da torrente dionisíaca, o que ocasionou outro fenômeno curioso. Contra esses poderes novos e formidáveis, levantou-se, ainda uma vez, o espírito apolínio na majestosa

2 Op. cit., p. 152. 
rigidez da arte dórica e na concepção dórica do mundo. A luta da individuação analítica da beleza contra o entusiasmo da absorção do homem da vida integral formou as grandes épocas da arte grega.

Para que ponto do infinito tendiam esses esforços, essas transformações, desde que não queiramos considerar a arte dórica como sua última manifestação e termo supremo dos instintos estéticos? Pergunta Nietzsche.

O agregado misterioso, resultante dessas batalhas, dissolveu-se na evolução histórica mediterrânea.

Os tempos modernos teriam tentado a sua reprodução?

Nietzsche, num estilo brilhante, quanto perturbador, às vezes incoerente, não raro desesperador inçado de sacrilégios, propõe a fórmula da sátiro do futuro.

A sua obra, que seguramente se assinalará, na literatura das nações modernas, como uma pretensão genial e, ao mesmo tempo, insensata, não faz outra coisa senão continuar o programa do Fausto, de Goethe.

O mundo ocidental também teve a sua luta de Titãs. Da Idade Média, emergiu o homem cheio de pavores, de sonhos, de enfermidades. Mal os destroços do Império Romano começaram a recompor-se em cidades, ao influxo do Renascimento e do Cristianismo surgiu a guerra antiga sob aspecto mais amplo e fulgurante.

Que tem sido a vida, sob essa vaga denominação de civilização senão a luta do indivíduo contra a crença, na forma do Estado?

Nietzsche pretendeu perscrutá-la. Deu-lhe uma solução? A super-humanidade terá visos de filosofia?

Qualquer que seja o destino do seu paradoxo em filosofia moral, é certo, porém, que a sua obra repercute a ansiedade trágica do fenômeno da moderna vida social. Não há quem leia os aforismos da Gaia Ciência, da Genealogia da Moral, do Acima do Bem o do Mal, do Assim falou Zaratustra, da Vontade de poder, que não experimente a surpresa de um pensamento infernal, escondido nas obras da própria consciência. 
Nietzsche arrojou-se a traduzir em livros, com a aparência de tratados filosóficos, o inferno da filosofia política, que se oculta sob o aspecto plácido, aparentemente tranquilo, dos compêndios profissionais de Leibniz, de Spinoza, de Bacon, de Descartes, de Kant, de Comte, de Spencer, de Schopenhauer e de Hartmann.

Explicar a vida!

Senti-la, exprimir artisticamente o seu mistério, isto começou a fazê-lo na época moderna, o gênio do poeta de Stratford-on-Avon.

Esta situação estética é bem provável que Nietzsche a compreendesse; e não parece sem significação o sátiro do futuro que ele imagina, nem será novidade que o sentimento trágico venha a constituir a verdadeira base da obra artística do século XX.

\begin{abstract}
Text published in the yearbook Almanaque Garnier, in 1904, on the Rio. It, Araripe Júnior seeks to address the tragic sense of the nineteenth century, therefore, part of the first book of the young Nietzsche, The origin of Tragedy. The author maintains that the tragic sense finding in young Nietzsche's work does not correspond to the Greek tragic sense, but the modern tragic feeling, particularly the nineteenth century.
\end{abstract}

Keywords: Nietzsche - tragic sense - The origin of Tragedy 